\title{
Conservative Islam And The Future Of A More Tolerant Society In Indonesia
}

\author{
Ahmad Abrori \\ Department of Sociology, Faculty of Social and Political Sciences, \\ State Islamic University Jakarta \\ Jakarta, Indonesia \\ ahmad.abrori@uinjkt.ac.id
}

\begin{abstract}
Conservatism is a powerful influencing movement in several countries. Indonesia, for example, encounters serious issues dealing with religious conflict because of religious conservatism. These things happen especially after the fall of Soeharto's regime in 1998 when this country could no longer control the resurgence of radical Islamic groups and the increasing hatred among communities based on religious and ethnic differences. Although religious conservatism among Muslims can be obviously observed, several researchers still deny this conservative turn in this Muslim majority country or at least deny that it has a negative influence. However, this essay will argue strongly that conservative Islam is now gaining ground among Indonesian Muslims, as well as prove that its impact on public spheres is dangerous. It will then establish the causes of this phenomenon, before recommending necessary measures to counter its influence. To support this, the research uses secondary data from well-publicized journals and electronic articles.
\end{abstract}

Keywords-conservatism; conservative Islam; religious conflict

\section{INTRODUCTION}

Indonesia has encountered serious religious conflict because of religious conservatism, which takes for granted what was written in the newspaper and deny liberal and modernist Islamic scholars re-interpretation [1]. It means that conservative Islam rejects to use modern hermeneutical methods for reading scripture and does not agree with the idea of secularization. Recently, the movement of conservative Islam into politics has also defined this growing shift to conservatism. It is reported that conservative Islam won the gubernatorial election in Jakarta by almost $10 \%$ by manipulating religious sentiment and accusing, as well as ultimately imprisoning the incumbent Christian candidate of religious blasphemy. Although religious conservatism among Muslims can be obviously observed, several researchers still deny this conservative turn in this
Muslim majority country or at least deny that it has a negative influence. However, this essay will argue strongly that conservative Islam is now gaining ground among Indonesian Muslims, and prove that its impact on the public sphere is dangerous. It will then establish the causes of this phenomenon, before recommending necessary measures to counter its influence.

\section{BECOMING MORE CONSERVATIVE}

Several researchers who are interested in the inter-religious issues argue that Indonesia is not becoming more religiously conservative and that it is still a tolerant country [2]. Under Pancasila, the philosophical basis of the governing state and society, any religious believers that have been recognized by the state (Muslim, Protestantism, Catholicism, Hinduism, Buddhism, and Confucianism) can feel free to practice their beliefs. Furthermore, religious freedom in this country is undoubtedly guaranteed by the Indonesian's constitution of 1945 [3]. Those who argue that Indonesia is a tolerant society point to the well-publicized occasions when this spirit of religious tolerance seems to have been demonstrated. For example, the district police of Central Java secured the ritual of one most controversial sects in Islam namely Syiah, when this sect successfully celebrated the 10 Muharram occasion to commemorate the mourning of the Prophet's grandchild named Husein, which take place in Semarang in 2015 [4]. These practices seem to indicate that Indonesia has no problem with religious intolerance.

However, Indonesian Islam is, in fact, becoming more conservative, increasingly intolerant, and more powerful. According to a prominent scholar of Indonesian Islam, van Bruinessen, conservatism has played a significant role in this country [5]. He provides the convincing example of this conservatism by referring to a fatwa of Majlis Ulama Indonesia (MUI, Indonesian Council of Islamic Scholars) in 2005. Through this 
fatwa, MUI declared that secularism, pluralism, and religious liberalism as deviant and incompatible with Islam. It does not only illustrate that MUI tends to ignore the diversity of Indonesian Islamic groups, but also confirms that MUI was inspired by several Islamic conservatives who have joined the council [6]. Another significant proof is the demanding of Islamic law enforcement in this secular country. It appeared during the democratic consolidation and decentralization era, beginning from the fall of the Soeharto regime in 1998 until 2008. In this transitional period, many Indonesian districts proposed the implementation of Islamic law, which is commonly labeled the Shariah law. There were 420 shariah by-laws approved by numerous district governments of thirty-three provinces in Indonesia[7]. Therefore, Indonesian Islam is now indeed more conservative and has entered not only religious sector but also in various public spheres.

Moreover, conservative Islam gives impacts on public life. It happened especially after the fall of New Order regime in 1998 when this country could no longer control the resurgence of conservative Islam and the increasing hatred between communities based on religious and ethnic differences. For example, the devastating outbursts of religious conflict happened in Poso, Central Sulawesi from 1998 until 2001, which resulted in an estimated death toll of between 1,000 and 2,500 people [8]. Furthermore, the violence happened in Ambon, the Moluccas in 1999 resulted in a total death toll of around 3,000 people [9], as well as in West Java in 2000, when strained relationships came up between Islam and Christianity due to the issue of missionaries, which has resulted in outbreaks of violence. Also, conservative Islam appears on electronic media, promoting conservative contents. They voice conservative Islam on their websites as another way of Jihad, total devotion to Islam, fighting against the Western press. It only creates a war in cyberspace and cultivates hatred among uncritical readers. Those situations indicate that conservative Islam has been absolutely coloring public life.

It is also argued that conservative Islam has had a limited political impact. Conservative Islam does not threaten the foundation of Indonesian state and democracy because it has never become a powerful movement. Therefore, this argument goes on, and it has constantly been defeated since the Post Colonial period [10]. However, in fact, conservative Islam plays a vital role in the political domain. Although the attempts for establishing the Islamic state by Indonesian Islamic State (Negara Islam Indonesia-NII) after colonial period have been silenced, this willingness was again voiced by Hizbuttahrir Indonesia (HTI). This transnational organization aims to establish Khilafah (a kingdom-like system) and implement Islamic law (as it is mentioned above, the idea of Islamic law enforcement once appeared during democratic consolidation). The purpose of this organization on the implementation Islamic law may be similar to the Prosperity Justice Party (PKS). As a right-wing party, PKS has been proven to gain considerable support from conservative Islam. This party was reported to win more than $50 \%$ of 101 recent district elections in 2017. These points are clear to Indonesia's future that is shifting to voice a conservative Islamic law implementation, which becomes a significant concern for Indonesia's national secular.

\section{THE CAUSES AND THE MEASURES}

The causes of the shift to conservatism have been debated. Fealy, a scholar who studies Indonesian Islam, claims that current emergence of conservative Islam is probably caused by liberal Muslims who share three controversial ideas on tolerant society. First of all, liberal Islam believes that the law of God is the only general universal principle. Secondly, Paramadina university intellectuals in Jakarta develop an inter-religious jurisprudential codes ('fikih lintas agama') to allow couples with different religions to get married. Thirdly, there are attempts for banning polygamy and enforcing equal inheritance rights by drafting Counter Legal Draft on the Islamic Law Compilation (CLD-KHI) [11]. These ideas provoked conservative groups to fight against liberal Muslims.

However, the cause of the resurgence of conservative Islam is not because of controversial statements from liberal Islamic groups. A widespreading traditional thought mainly causes it through Islamic educational institutes. Currently, the characters of Islamic education in Indonesia can be seen from the increasing number of majlis taklims, non-formal voluntary Islamic educational institutions belonging to local religious communities, as well as Integrated Islamic Schools (IIS), which is a popular formal Islamic educational institute belonged to PKS. In many majlis taklims, members are mostly new learners of Islamic teaching [12]. They have not experienced the formal Islamic educations which are commonly conducted by the madrasah, pesantren, or other Islamic schools. Also, the clerics are more focused on basics of Islamic principle and avoid teaching members of majlis to read scripture critically. Preferably, the clerics tend to teach them the literal comprehension of the scripture.

Moreover, in the Integrated Islamic Schools, students are taught by PKS activists. Surprisingly, 
the schools are popular among middle-class Muslims because their alumni succeeded to go into top Indonesian universities [13]. Behind this, the schools design the revival of the golden age of Islam as their hidden agenda. To fulfill this agenda, the schools take Wahabi doctrine into their Islamic courses which refer to Wahabi books, such as Kitab al-Tawid by the Wahhabi founder Muhammad 'ibn Abd al-Wahhab (1703-1792) or al-Qawl al-Shadid 'alá Kitab al-Tawhid by 'Abd al-Rahman al-Su'udi (Hasan, 2012). These circumstances probably cause the resurgence of conservative Islam in Indonesia.

Considering those circumstances, the state must take the measures to guarantee the future of a more tolerant society. The state must have policies to promote religious tolerance systematically through education, media regulation, and communication. Regarding education, the state should disseminate inclusive values, such as intensively teaching Pancasila principles and minimizing the teaching of traditional religious beliefs at schools. Pancasila principles should be the primary reference to internalize shared civic culture among the students. Although the result of this may appear in next generations, it can at least minimize the negative impacts of the growing conservatism. Regarding the media, the state must provide a regulation in reducing hate speech. For example, it is strictly banned to share hoaxes for media users and put to sentence those who break the law. Even though it seems to be a normative policy, once the law is enforced, it will minimize the spreading of hate speech. It is frequently found that sharing hate speech through media triggers a public conflict among different groups. Last but not least, the state must play an important role as a mediator between these opposing groups. The aim is to encourage both conservative and liberal Islam to respect each other. Although it is challenging because the government staffs are usually fulfilled by certain political cadres who perhaps have defined position between opposite groups, the government must show its great nationalism and maturity in politics. Therefore, they must find the middle ground since both conservative and liberal Islam has had a different perspective about Islam and the way of life.

\section{CONCLUSION}

In conclusion, conservative Islam is now a more powerful and challenging liberal Islam in Indonesia. Although several scholars argue that conservative Islam seems to have no problem with tolerance issues, the evidence suggests that regarding religious freedom, public life, and politics, this conservatism jeopardizes the future of tolerance in Indonesian society. Before introducing measures to deal with this problem, it is important to know the significant causes of the increasing conservatism in Indonesian Islam. By understanding the causes, and by encouraging the state to set policies in inclusive education, hate speech regulation, and impartial communication between conservative and liberal Islam, it is possible to limit the negative consequences of this threat. It is also important to undertake further research into the relationship between religion and the state, as well as to ensure that the two remain separate.

\section{References}

[1]. L. Assyaukanie, L. "Contemporary Developments in Indonesian Islam: Explaining the 'Conservative Turn' in Bulletin of Indonesian Economic Studies. Vol 49 (3), 2013, pp. 394-395.

[2] L. Parker, "Teaching Religious Tolerance in Inside Indonesia" 102, 2010.

[3] L. Parker, "Teaching Religious Tolerance in Inside Indonesia" 102, 2010

[4] "Wahid Foundation: Toleransi di Indonesia Terus Meningkat" in Detik.com. Retrieved April 30, 2017

[5] M. van Bruinessen, "What Happened To The Smiling Face of Indonesian Islam? Muslim Intellectualism And The Conservative turn In Post-Suharto Indonesia" in RSIS Working Papers. No. 222, 2011.

[6] M. van Bruinessen, "What Happened To The Smiling Face of Indonesian Islam? Muslim Intellectualism And The Conservative turn In Post-Suharto Indonesia" in RSIS Working Papers. No. 222, 2011.

[7] M. Buehler, "State Management of Religion in Indonesia, by Myengkyo Seo; The Roots of Terrorism in Indonesia: from Darul Islam to Jema'ah Islamiyah, by Solahudin; Contemporary developments in Indonesian Islam: explaining the 'Conservative Turn', by Martin van Bruinessen" in Democratization, Vol 22 (3) 2015.

[8] L. V. Aragon, "Waiting For Peace In Poso in Inside Indonesia, Vol 70, 2002

[9] C. Wilson, "The Ethnic Origins of Religious Conflict in North Maluku Province, Indonesia, 1999-2000" in Indonesia. No. 79. , pp. 69-91, 2005.

[10] K. Hamayotsu, "Conservative Turn: Religion, State and Conflict in Indonesia" in Pacific Affairs Vol 87 [4], 2014.

[11] G. Fealy, "A Conservative Turn in Inside Indonesia", 87. Retrieved April 30, 2017

[12] F. N. Stiftung and Goethe Institute, "Tata Nilai, Impian, Cita-cita Pemuda Muslim di Asia Tenggara: Survei di Indonesia dan Malaysia" 2010.

[13] N. Hasan, "Education, Young Islamists And Integrated Islamic Schools In Indonesia" in Studia Islamika. Indonesian Journal For Islamic Studies. Vol 19 (1) 2012 . 